\title{
ENVIRONMENTAL QUALITY ASSESSMENT OF THE DRAINAGE BASIN OF LAKE ENGURE USING SCOTS PINE AS A BIOINDICATOR
}

\author{
Ināra Melece*, Aina Karpa**, Māris Laiviņš**, and Viesturs Melecis** \\ * Faculty of Geography and Earth Sciences, University of Latvia, Rīga, Alberta iela 10, LV-11010, LATVIA, \\ e-mail: inaramelece@inbox.Iv \\ ** Institute of Biology, University of Latvia, Miera iela 3, Salaspils, LV-2169, LATVIA
}

Contributed by Viesturs Melecis

\begin{abstract}
Environmental quality assessment of the Lake Engure drainage area, which is the LT(S)ER region of the Latvian National Long-term Ecological Research network (Latvia LTER), was conducted using three bioindication methods based on Scots pine Pinus sylvestris L.: unspecific bioindication by pine needle tip necrosis, ground level ozone assessment by pine needle chlorotic mottling, and chemical analysis of pine bark. Samples were collected from 40 sites of the region in November 2010. Extent of needle tip necroses did not exceed class 4 (maximum possible value 6). The highest value of index of needle damage by ozone was Idam $=1.62$ (maximum possible value 6). Multiple regression analysis of variables describing bark chemistry and needle damage in relation to distance from the sea, nearest roads and villages was performed. Pine bark acidity $\mathrm{pH}(\mathrm{KCl})$ and concentration of $\mathrm{Mg}$ and $\mathrm{Fe}$ decreased significantly $(\beta \mathrm{pH}(\mathrm{KCl})=-0.672, \mathrm{P}<$ $\left.0.001 ; \beta \mathrm{Mg}=-0.676, \mathrm{P}<0.001 ; \beta_{\mathrm{Fe}}=-0.514, \mathrm{P}<0.001\right)$ with distance of sample site from gravel roads. Electric conductivity $(E C)$ of pine bark and the extent of ozone damage of the first year needles I dam significantly decreased with distance from the sea $\left(\beta_{\mathrm{ozone}}=-0.507, \mathrm{P}<0.01 ; \beta_{\mathrm{EC}}=\right.$ $-0.453, \mathrm{P}<0.01$ ). PCA of the pine bark chemistry data showed dust pollution from gravel roads to be the main factor responsible for the $33 \%$ variation of data. No statistically significant correlations were found between different bioindicator characteristics, except between first and second year ozone damage $(\rho=0.589, \mathrm{P}=0.01)$.
\end{abstract}

Key words: $L T(S) E R$ region, ground level ozone damage, Pinus sylvestris, chemistry of pine bark, pine needle necroses.

\section{INTRODUCTION}

The ILTER (International Long Term Ecological Research) network is a global "network of networks" of research sites located in a wide array of ecosystems worldwide, which can help to understand long-term environmental change across the globe. In 2010, the network included 38 countries all over the world (Anonymous, 2011a). In 2008, a new research strategy was set forward by the ILTER community, which focused on threshold interaction between environmental and socio-economic dynamics at multiple scales and possibly forecast of the effects of these interactions on biodiversity and ecological resilience, with the aim to slow the rate of anthropogenic biodiversity loss. Undoubtfully, one of the most important anthropogenic pressures responsible for significant biodiversity reduction is environmental pollution (Anonymous, 1970). This should be considered when implementing the environmental assessment strategy for LT(S)ER (Long Term Socio-ecological Research) regions. However, the total long-term environmental screen- ing of thousands of chemical compounds emitted by industry, transport and household in a region and mapping their concentration gradients is not possible. On the other hand, the most important question does not concern the absolute concentrations of a particular pollutant in the environment, but rather, the reaction of ecosystems and species to the pollutant (Balodis et al., 1993). There is no better indicator of the status of a species or a community than the species or the community itself (Tingey, 1989). Bioindication methods are much more suited for mapping of environmental state in particularly large territories, because (i) they are much cheaper than methods of chemical analysis, (ii) living organisms are permanently subjected to pollutants, (iii) organisms reflect integrated effects of various chemical compounds, and (iv) organisms reflect interactions of pollutants with natural environmental factors (Knabe, 1982; Balodis et al., 1993; Holt and Miller, 2011; Geras'kin et al., 2011). Plants, particularly trees, are frequently used as bioindicators in air quality assessment, as (i) they do not change their position within the landscape, (ii) they are permanently 
subjected to pollutants, (iii) they are long-lived organisms that reflect long-term pollution effects (Weinstein and Laurence, 1989; Balodis et al., 1993; Geras'kin et al., 2011). In regions with northern and moderate climate, conifers, in particular Pinus species, are frequently used because their evergreen needles are exposed to air pollution throughout the year, and according to numerous studies (see e. g. Jäger, 1980; Miller et al., 1995; Pöykiö et al., 2010) they are highly sensitive to environmental stress.

The LT(S)ER region of Latvia (Anonymous, 2011b) (Engure region) represents the drainage area of coastal Lake Engure $\left(644 \mathrm{~km}^{2}\right)$, part of which is included in the territory of the Lake Engure Nature Park, with the Ramsar site as its core. At present, there are no big industries or intensive agriculture in the region, and the data obtained in the present survey could serve as a good background in future studies after a period of land-use change. Scots pine Pinus sylvestris was selected as a bioindicator for environmental assessment of the LT(S)ER region, as the area is rich in forests dominated by this species. In 2010, bioindication investigations were performed at 40 sites located throughout the region. Three bioindicative features were used in the assessment: (i) pines needle tip necroses; (ii) chlorotic mottling of needles induced by ground level ozone, and (iii) chemistry of pine bark (metal concentration, $\mathrm{pH}$, and electric conductivity). Pine needle tip necroses can be regarded as nonspecific bioindication. This method was elaborated by German researchers (Jäger, 1980; Schubert, 1991) for mapping of $\mathrm{SO}_{2}$ pollution around industrial enterprises. Later, similar symptoms were described for fluoride and chlorine (Rozhkov and Mikhailova, 1993; Choi et al., 2006), and nitrogen oxide emissions (Smith, 1990). Also concentrations of some trace metals in needles have shown correlation with tip necroses (Rautio et al., 1998). Magone (1992) adapted this method for environmental assessment in Latvia and it has been used for many years with some modifications in the framework of the state environmental monitoring programme (Magone et al., 1992; Balodis et al., 1993; Anonymous, 2005). Chlorotic mottling of pine needles is a specific ozone response variable described in the 1960s (Linzon, 1960; Richards et al., 1968) and which later has been studied by many researchers (see e. g. Miller et al., 1995). Pine bark has been widely used as an accumulative indicator for air pollution by heavy metals (see e. g. Grodzińska, 1977; Nikodemus et al., 1993; Lippo et al., 1995; Harju et al., 2002; Kord and Kord, 2011).

The purpose of this paper was to evaluate the results of environmental assessment of the LT(S)ER region of Latvia (drainage area of coastal Lake Engure) obtained by different bioindication methods and to select the most suitable method for mapping of environmental stress in the territory. Concentrations of pollutants emitted by one source as a rule are highly correlated (Berina et al., 1989; Karps et al., 1989). We hypothesised that also bioindicative responses of the same species to these pollutants would be correlated. This could simplify the environmental assessment procedure of the LT(S)ER region, by decreasing the number of necessary analyses.

\section{MATERIALS AND METHODS}

Characteristics of the drainage area of Lake Engure. The LT(S)ER region of Latvia (Engure region) includes the drainage area $\left(644 \mathrm{~km}^{2}\right)$ of Lake Engure - a remnant of the Littorina Sea formed about 4000 years ago. The territory includes the Lake Engure Nature Park, a Ramsar site with unique inland and marine wetlands. Most of the drainage area is covered by pine forests, but there are also large areas of marshlands, meadows, deciduous forests, dunes and agricultural lands. The ecosystems of the area have been altered by various human activities that are historically well documented, such as regulation of water level, hay making, pasturing, hunting, and fishery. The traditional settlement types were fishing villages characterized by linear structures along the seashore and farmsteads inland. Agriculture landuse and industry (fishing and fish processing) in the region have sharply declined since 1991 .

Selection of sampling sites. In 2010, forty sampling sites were selected in the drainage area of Lake Engure (Fig. 1).

The sample sites were selected according to the following principles:

- the sample trees were located such that the area in the South-East, South, and South-West direction to each tree was open without a tree canopy;

- plots were not selected in areas where vegetation was suffering from drought or excessive moisture;

- sample trees (pines) had age at least 20 years.

The selection of sampling points was made according to availability of suitable pine stands within the region. The area between Lake Engure and the sea coast was sampled more intensively due to location close to an intensively used highway and also several big fishing villages, which may affect air quality. Some parts of the region were not suitable for sampling. The central part of the region was occupied by wet forests on peaty soils and the South-West part was dominated by agricultural lands where pine stands were not found.

Sampling and assessment of needle damage. Sampling of pine needles was performed in November 2010. At each sample site pine needles were taken from 10 trees. Twigs were cut by special twig scissors at at a height of 4-5 m on the sun-exposed side of the tree. The twigs were transported to the laboratory in plastic bags. In the laboratory 100 needles of the current year (first-year needles) and 100 needles of the previous year (second-year needles) were randomly collected from the twigs of each tree. The period of exposure of the first year needles was six months, and the period of exposure on of the second year needles was 14 months. In total 1000 needles of the first and second year were sampled from each site.

Pine needles were inspected for damage under a dissecting microscope to distinguish injuries caused by environmental 

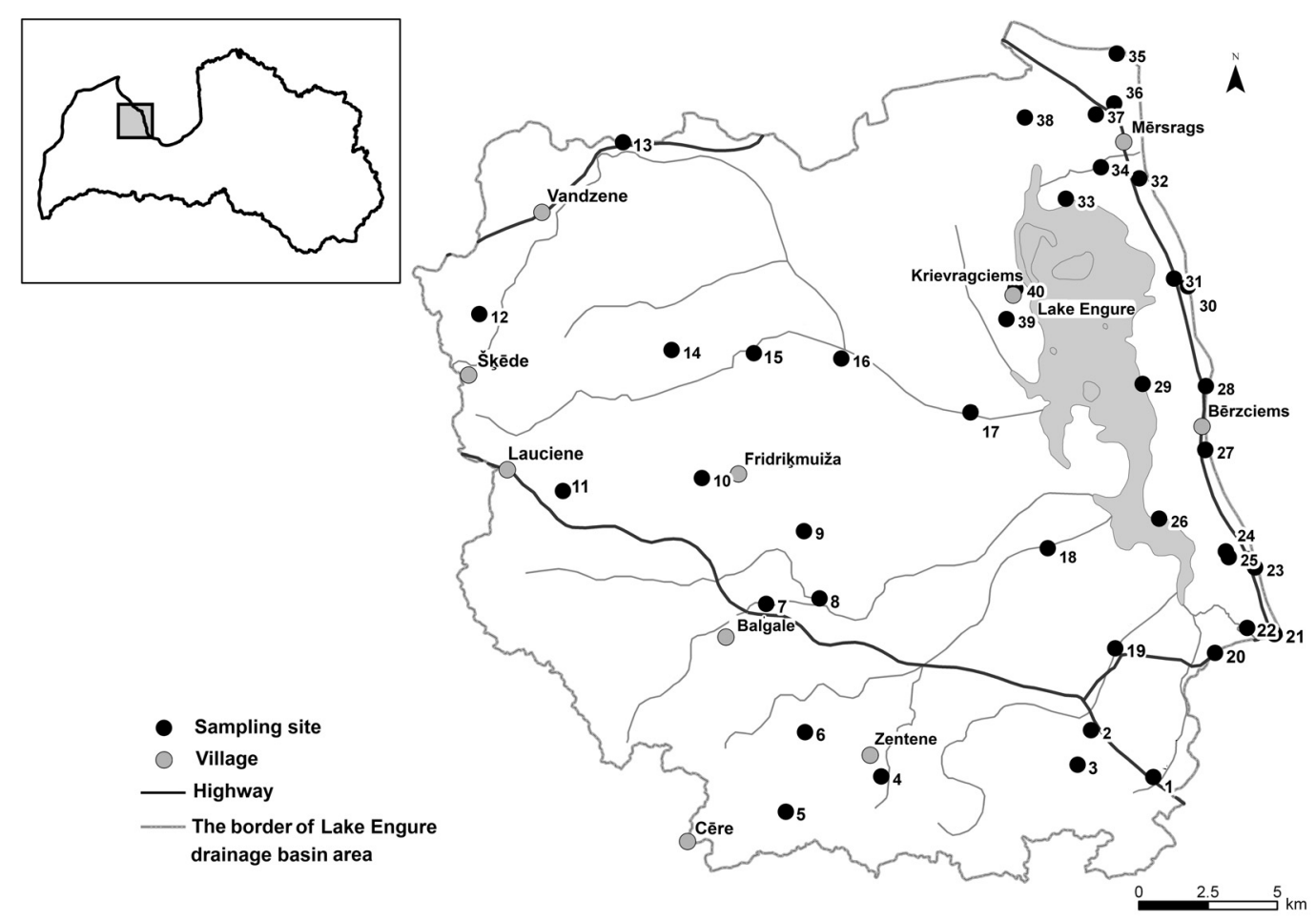

Fig. 1. Location of sample sites within the Engure LT(S)ER re-

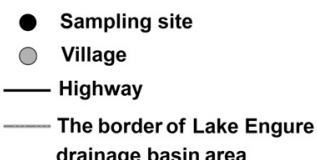

drainage basin area factors from those of insects and plant pathogens. The method of unspecific bioindication based on pine needle necroses (Jäger, 1980) was used for the first year needles according to a 6-grade scale:

$1^{\text {st }}$ class - no signs of damage;

$2^{\text {nd }}$ class - needle tips chlorotic, yellowish;

$3^{\text {rd }}$ class - needle tips necroticised, brown;

$4^{\text {th }}$ class - necrosis of the whole top part of the needle;

$5^{\text {th }}$ class - necroses of a third part of the needle;

$6^{\text {th }}$ class - entire needle necroticised, brown.

The extent of pine needle damage did not reach the $5^{\text {th }}$ and $6^{\text {th }}$ class in the Engure region, as there are no large air pollution sources in the area. For this reason, we introduced a subclass $1 \mathrm{a}$ between classes 1 and 2 for needles with slightly chlorotic, pale tips (the theoretically possible number of classes in our study was 7).

Ground level ozone causes chlorotic mottling over the surface of pine needles. According to the method of Calatayud (Anonymous, 2001) needles are classified into six classes, ranging from healthy ( 0 score) to heavily damaged, chlorotic needles ( 5 score). In our study, the extent of ozone damage appeared to be low (0-2 score according to Calatayud) comprising only three classes. Therefore, we used a slightly transformed Calatayud's scale:

0 class - no ozone damage;

$1^{\text {st }}$ class $-1-3 \%$ chlorotic mottling;

$2^{\text {nd }}$ class $-3-5 \%$ chlorotic mottling; $3^{\text {rd }}$ class $-5-10 \%$ chlorotic mottling;

$4^{\text {th }}$ class $-10-15 \%$ chlorotic mottling;

$5^{\text {th }}$ class $-15-25 \%$ chlorotic mottling.

Sampling and chemical analysis of pine bark. Samples of the surface layer of pine bark $(1 \mathrm{~mm})$ were collected from all four compass direction of the trees at $1.3 \mathrm{~m}$ height. $1.5 \mathrm{~g}$ of air dried material was mineralised in $15 \mathrm{ml}$ of concentrated $\mathrm{HNO}_{3}$ for two hours and then diluted to $25 \mathrm{ml}$ of distilled water. Concentrations of metals ( $\mathrm{Na}, \mathrm{Mg}, \mathrm{K}, \mathrm{Ca}, \mathrm{Mn}$, $\mathrm{Fe}, \mathrm{Ni}, \mathrm{Cu}, \mathrm{Zn}, \mathrm{Cd}$, and $\mathrm{Pb}$ ) were determined by a AAS PerkinElmer AAnalyst 200 with flame atomisation. pH of pine bark was determined in $1 \mathrm{n} \mathrm{KCl}$, and electric conductivity (EC) in water solution.

Data analysis. For estimation of the extent of needle damage by ozone, the index $I_{d a m}$ was calculated:

$I_{\text {dam }}=\sum_{i=1}^{m} K_{i} \cdot i$.

where $K_{i}$ is the proportion of damaged needles belonging to $i$-th class; $\mathrm{i}=1$. 2. 3. ... $\mathrm{m} ; \mathrm{m}$ - number of classes. $I_{\text {dam }}$ varies between 1 and the maximum number of classes. If $I_{d a m}=1$ no damage was observed. The maximum $I_{d a m}$ of 6 is reached when all needles are heavily damaged. Values of $I_{d a m}$ were obtained for each tree in a sample site; mean values and standard errors were calculated for sites.

Geographical coordinates of each sample site were determined by GPS and entered on a digital map of the region. The nearest distance of each sampling site from the sea coast, gravel road, highway, and village was determined from the digital maps.

Correlation analysis was used to determine relationships among various indicators. Multiple linear regression was 
used to determine the effect of distances to sea, nearest road and village on bioindication and chemical characteristics of pine bark. Data distribution was checked for normality and data sets with strong asymmetry were log-transformed before analysis. Calculations were performed using the programme package SPSS. PCA was used to combine covariable metal concentrations in pine bark into components. VARIMAX rotation was performed and the randomization test Rnd-Lamda was used to select the number of PCA axes.

\section{RESULTS}

The structure of land use and distribution of pine forests, and hence also of sampling sites, were not evenly distributed within the Engure LT(S)ER region (Fig. 1). The SW part of region was dominated by agricultural land, and the central part by forests on wet peaty soils, which were not suitable as sample sites. The availability of bioindicators placed restrictions on the arrangement of sample sites within the region.

$57.5 \%$ of the collected first year pine needles (exposure six months) from 23 sample plots belonged to the $1^{\text {st }}$ and $1 \mathrm{a}$ class. $35 \%$ of needles collected from 14 sample plots belong to $2^{\text {nd }}$ and $3^{\text {rd }}$ class and only $7.5 \%$ of needles collected from three sample plots - to the $4^{\text {th }}$ class (Fig. 2).

Needles with ozone induced mottling were found in all 40 sample plots. However, the extent of damage did not exceed $15 \%$ and in most cases was only 3-5\%. Second-year needles (exposure 14 months) were found to be much more damaged by ozone. On some sample plots the proportion of ozone-affected pine needles exceeded $50 \%$. The index of damage $I_{d a m}$ varied between 1 and 1.1 for the first-year needles and between 1 and 1.62 for the second-year needles.

Considerable variation in metal content of pine bark was found within the sampling plots of the region (Fig. 3).

The highest range in concentrations of heavy metals was found for $\mathrm{Pb}$ an $\mathrm{Ni}$ (accordingly 71 and 31 times). Variation

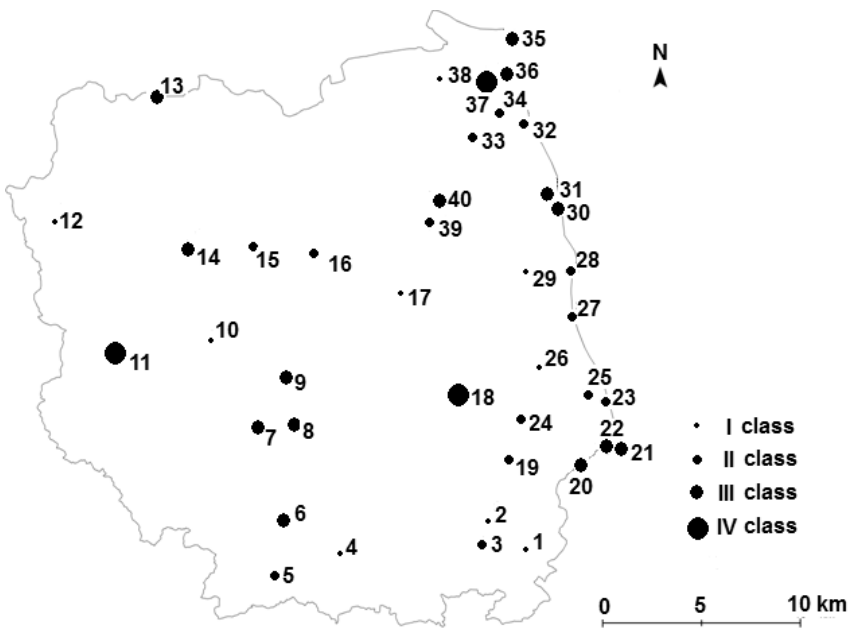

Fig. 2. Development of pine needle necroses at selected sample sites of Engure LT(S)ER region. Necrotisation classes (I-IV) are marked by circles of different size. in concentrations of $\mathrm{Mg}$ and $\mathrm{Fe}$ did not exceed 20 times, and that of other chemical elements by 10 times. The lowest range in concentration (two times) was found for potasium. Also, the ranges in values of $\mathrm{EC}$ and $\mathrm{pH}(\mathrm{KCl})$ were quite high, two and three times, accordingly.

Multiple regression analysis of variables yielded five statistically significant equations that explained the effect of distance from the sea, nearest road and village on pine bark chemistry and needle damage (Table 1). However, for each of the multiple regression equations, only one predictor was found to be significant in $t$-tests. Acidity of pine bark increased with decreasing distance from gravel roads $(\beta=$ -0.672, $P<0.001)$. A similar relationship was found for content of $\mathrm{Mg}(\beta=-0.676, P<0.001)$ and $\mathrm{Fe}(\beta=-0.514$, $P<0.001)$. Electric conductivity of pine bark increased with decreasing distance from the sea $(\beta=-0.453, P<$ 0.01 ). Of the bioindicative characteristics tested by multiple regression, only ozone damage $I_{d a m}$ index for first year pine needles showed a statistically significant decrease with distance from the sea $(\beta=-0.507, P<0.01)$.

\begin{tabular}{|c|c|}
\hline Variables & $\begin{array}{c}\text { Statistical } \\
\text { characteristics }\end{array}$ \\
\hline $\mathrm{Na}$ & $\underset{35-86-172}{H}$ \\
\hline K & 216-314-430 \\
\hline $\mathrm{Mg}$ & $\underset{106-383}{\prod_{A}-1724}$ \\
\hline $\mathrm{Ca}$ & $\underset{2656-5287-12081}{H \mid \cdots}$ \\
\hline Mn & 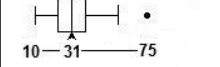 \\
\hline $\mathrm{Fe}$ & $\underset{59-184-}{H} \prod_{682}$ \\
\hline $\mathrm{Ni}$ & $\underset{0.03-0.43-1.05}{\longmapsto}$ \\
\hline $\mathrm{Cu}$ & $\underset{2.5-3.7-12.0}{H \mid}$ \\
\hline $\mathrm{Zn}$ & $\stackrel{\prod_{11.3}-20.3-33.3}{\vdash} \cdot$ \\
\hline Cd & $\underset{0.08-0.27-0.48}{\mapsto \bigsqcup}$ \\
\hline $\mathrm{Pb}$ & 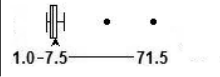 \\
\hline EC & $\mid$\begin{tabular}{l|l}
$\mid$ \\
$0.19-0.34-0.58$
\end{tabular} \\
\hline $\mathrm{pH}$ & 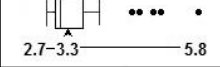 \\
\hline
\end{tabular}

Fig. 3. Pine bark chemistry data obtained from sample sites in the Engure $\mathrm{LT}(\mathrm{S})$ ER region. Values of metal concentration are in $\mathrm{mg} / \mathrm{kg}$, electric conductivity $\mathrm{EC}$ in $\mathrm{mS} / \mathrm{cm}$. The line in the middle of the boxplot represents the median value of the variable. $50 \%$ of the data lie in the box, lower $25 \%$ and upper $75 \%$ quartiles are shown. Approximately $95 \%$ of data are expected to lie within the range of T-bars if the data have normal distribution. Black dots are outliers. Min-mean-max values are given. Means are shown by arrows. 
MULTIPLE REGRESSION ANALYSIS OF DEPENDENCE OF METAL CONTENT IN PINE BARK, pH(KCl), ELECTRIC CONDUCTIVITY EC AND BIOINDICATIONAL CHARACTERISTICS ON PREDICTORS ${ }^{1}$

\begin{tabular}{|c|c|c|c|c|c|}
\hline \multirow[t]{2}{*}{ Dependent variable } & \multirow{2}{*}{$\begin{array}{c}\text { Evaluation of regression } \\
\text { equation }\end{array}$} & \multicolumn{4}{|c|}{ Predictors } \\
\hline & & $\begin{array}{c}\text { distance from nearest } \\
\text { village }\end{array}$ & $\begin{array}{c}\text { distance from } \\
\text { sea }\end{array}$ & $\begin{array}{c}\text { distance from gravel } \\
\text { road }\end{array}$ & $\begin{array}{c}\text { distance from } \\
\text { highway }\end{array}$ \\
\hline $\mathrm{Mg}$ content in pine bark & $\begin{array}{c}\mathrm{F}_{4,35}=8.175, P \text { plain } 0.0005 \\
\quad \text { Adjusted R square }=0.424\end{array}$ & $\begin{array}{l}\beta=-0.60 \\
P=0.633\end{array}$ & $\begin{array}{l}\beta=0.003 \\
P=0.980\end{array}$ & $\begin{array}{c}\beta=-0.676 \\
P=0.00\end{array}$ & $\begin{array}{l}\beta=0.011 \\
P=0.941\end{array}$ \\
\hline Fe content in pine bark & $\begin{array}{r}\mathrm{F}_{4,35}=3.583, P \text { plain } 0.05 \\
\text { Adjusted R square }=0.209\end{array}$ & $\begin{array}{l}\beta=0.054 \\
P=0.714\end{array}$ & $\begin{array}{l}\beta=0.100 \\
P=0.54\end{array}$ & $\begin{array}{l}\beta=-0.514 \\
P=0.009\end{array}$ & $\begin{array}{l}\beta=-0.038 \\
P=0.832\end{array}$ \\
\hline $\begin{array}{l}\text { EC electric conductivity of } \\
\text { pine bark }\end{array}$ & $\begin{array}{l}\mathrm{F}_{4,35}=3.583, P \text { plain } 0.05, \\
\text { Adjusted } \mathrm{R} \text { square }=0.209\end{array}$ & $\begin{array}{l}\beta=-0.157 \\
P=0.278\end{array}$ & $\begin{array}{l}\beta=-0.453 \\
P=0.007\end{array}$ & $\begin{array}{l}\beta=0.060 \\
P=0.740\end{array}$ & $\begin{array}{l}\beta=-0.223 \\
P=0.208\end{array}$ \\
\hline $\mathrm{pH}(\mathrm{KCl})$ of pine bark & $\begin{array}{c}\mathrm{F}_{4,35}=5.563, P=0.001, \\
\text { Adjusted } \mathrm{R} \text { square }=0.319\end{array}$ & $\begin{array}{l}\beta=-0.086 \\
P=0.530\end{array}$ & $\begin{array}{l}\beta=-0.068 \\
P=0.655\end{array}$ & $\begin{array}{l}\beta=-0,672 \\
P=0.000\end{array}$ & $\begin{array}{l}\beta=-0.080 \\
P=0.632\end{array}$ \\
\hline $\begin{array}{l}\text { Index of ozone damage } I_{d a m} \\
\text { for first year pine needles }\end{array}$ & $\begin{array}{l}\mathrm{F}_{4,35}=3.948, P=0.010, \\
\text { Adjusted } \mathrm{R} \text { square }=0.232\end{array}$ & $\begin{array}{l}\beta=0.083 \\
P=0.567\end{array}$ & $\begin{array}{l}\beta=-\mathbf{0 . 5 0 7} \\
P=\mathbf{0 . 0 0 3}\end{array}$ & $\begin{array}{l}\beta=-0.181 \\
P=0.326\end{array}$ & $\begin{array}{l}\beta=-0.246 \\
P=0.168\end{array}$ \\
\hline
\end{tabular}

$\overline{{ }^{1} \text { Only statistically }}$ significant equations are shown. Characteristics of significant predictors are in bold.

Based on Rnd-Lamda criterion $(P<0.05)$ three PCA axes were extracted from the correlation matrix of pine bark chemistry data. The first axis explained $33 \%$ of the total variance (Table 2).

PCA component 1 was best correlated to $\mathrm{pH}$ and concentration of $\mathrm{Mg}, \mathrm{Ca}$ and Fe. Distance to the closest gravel road was also significantly correlated, but negatively $(\mathrm{r}=-0.609$, $P<0.001$ ), with this axis (Fig. 4).

The second axis explained $19 \%$ of the total variance and was strongly correlated with $\mathrm{Pb}, \mathrm{Cu}$ and $\mathrm{Ni}$. The third axis explained $14 \%$ of variance and was negatively correlated with $\mathrm{EC}$ and $\mathrm{K}$.

Table 2

CORRELATIONS BETWEEN FIRST 3 PCA COMPONENTS AND VARIABLES, AND PROPORTION OF VARIANCE EXPLAINED BY PRINCIPAL AXES ${ }^{1}$

\begin{tabular}{l|c|c|c}
\hline \multirow{2}{*}{$\begin{array}{c}\text { Chemical } \\
\text { variables }\end{array}$} & \multicolumn{3}{|c}{ Principal axes } \\
\cline { 2 - 4 } $\mathrm{Mg}$ & 1 & 2 & 3 \\
$\mathrm{PH}$ & 0.964 & & \\
$\mathrm{Ca}$ & 0.935 & & \\
$\mathrm{Fe}$ & 0.879 & & \\
$\mathrm{Zn}$ & 0.798 & & \\
$\mathrm{~Pb}$ & 0.601 & & \\
$\mathrm{Cu}$ & & 0.868 & \\
$\mathrm{Ni}$ & & 0.714 & \\
$\mathrm{Na}$ & & 0.697 & \\
$\mathrm{~K}$ & & 0.523 & \\
$\mathrm{EC}$ & & & 0.703 \\
$\mathrm{Mn}$ & & & 0.637 \\
$\mathrm{Cd}$ & & & -0.627 \\
Total variance explained, \% & 33 & 0.511 & -0.521 \\
Cumulative variance, \% & 33 & 52 & 14 \\
\hline
\end{tabular}

\footnotetext{
${ }^{1}$ Results of PCA of the data of chemical analysis of pine bark collected at 40 sites in the drainage area of Lake Engure. Only correlations $\geq 0.500$ are shown.
}

No significant correlations were found between characteristics of pine needle tip necrosis and ozone damage as well as between these bioindicative characteristics and metal concentrations in of pine bark. A significant correlation was found between $I_{d a m}$ for ozone damage in the first- and second-year pine needles (Fig. 5).

\section{DISCUSSION}

Environmental assessment of the Engure LT(S)ER region using pine needle tip necroses as an indicator showed relatively low environmental stress in comparison with some other regions of Latvia, where local industries and intensive agriculture have caused pine needle necroses even at the level of the $5^{\text {th }}$ class (Magone et al., 1992; Balodis et al., 1993). In the Engure region, where there are no big cities and industries, maximum needle damage did not exceed the $4^{\text {th }}$ class, which was observed only at three sites $(11,18$, and 37) located in different parts of the region (Fig. 1). The

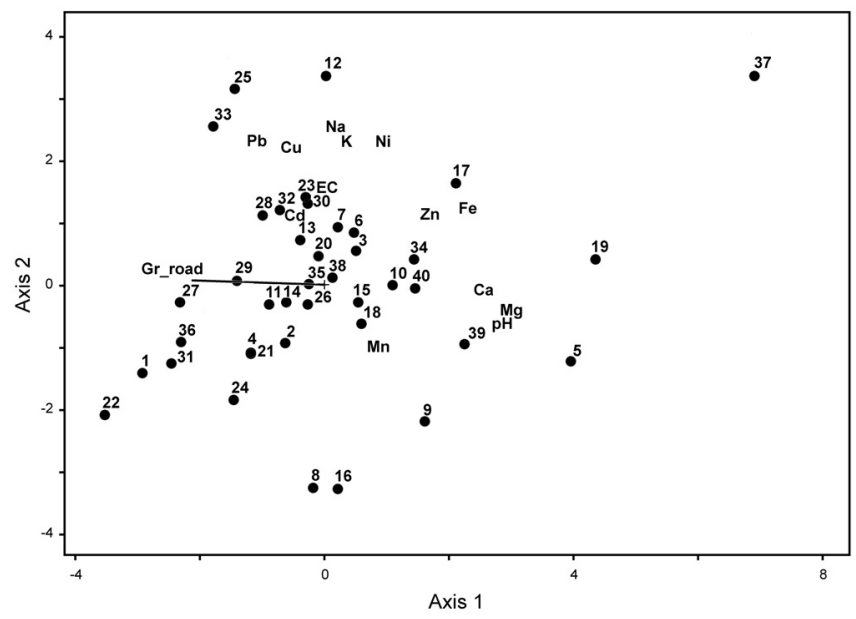

Fig. 4. Biplot of sample sites of Engure LT(S)ER region and variables characterising pine bark chemistry data in a PCA ordination. Gr_road variable vector describing correlation of the PCA component 1 with distance of sample plots from the gravel roads $(\mathrm{r}=-0.609, P<0.001)$. 


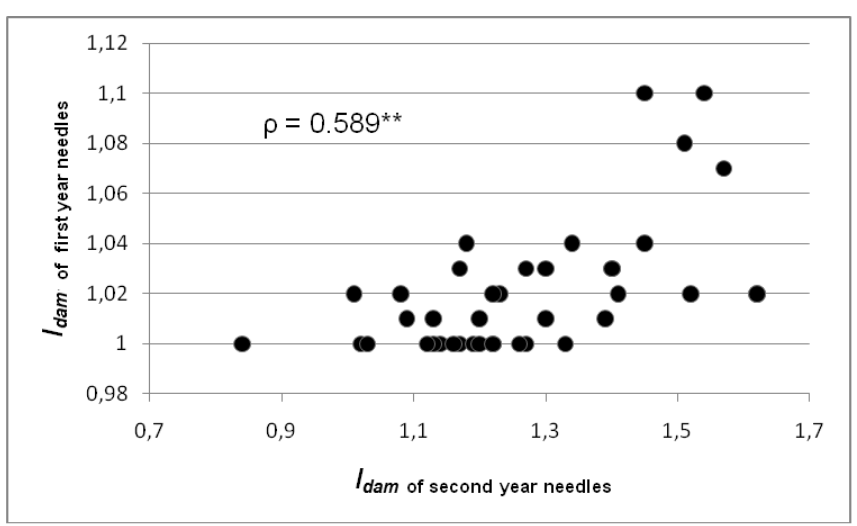

Fig. 5. Correlation between damage index $I_{d a m}$ calculated on the basis of ozone-induced pine needle mottling for first and second year needles at sample sites in the Engure LT(S)ER region. - Spearman correlation coefficient significant at $P=0.01$.

sites were quite different in relation to possible causes of environmental stress. Only two of the three were located near roads, and thus damage due to road dusts or vechile emissions is not the sole cause. Evidently there were some other unrevealed local sources of environmental stress.

Ozone damage to pine needles was also low $\left(I_{\text {dam }} 2\right)$ but temporally continuous for particular sites, as shown by correlation between index values calculated for two successive periods -6 and 14 months. The extent of damage increased with the period of exposure. Ozone damage was greater near the sea. This is consistent with the data of some other authors (Piikki et al., 2008). However, dependence of $I_{d a m}$ on distance to the sea was statistically significant only for first year needles. Evidently, accumulation of ozone damage differed during the period of exposure and slightly varied from site to site. Chemical analyses of pine bark showed high variation in concentrations of metals as well as $\mathrm{pH}$ and $\mathrm{EC}$ values within the region (Fig. 3). It was difficult to compare the metal contentrations in pine bark of the region with those obtained in previous studies in other locations of Latvia, due to differences in methods of chemical analysis and sensitivity of analytical equipment. For example, in the densely populated Jūrmala region, where air pollution effects were studied in 1993 (Nikodemus et al., 1993), pine bark contained 3-4 times more $\mathrm{Fe}, \mathrm{Cd}$ and $\mathrm{Pb}$ than in the Engure region, while pine bark in the Engure region contained about $20 \%$ more $\mathrm{Ca}, \mathrm{Mg}$ and $\mathrm{Mn}$ than in Jūrmala. In the begining of the 1990s, Jürmala suffered from the consequences of industrial pollution from a paper mill and intensive transport. The main factor related to metal concentrations of bark in the Engure region, as shown by PCA, was distance to gravel roads. The first PCA component was related to concentrations of metals $(\mathrm{Ca}, \mathrm{Mg}, \mathrm{Fe}$ a. o.) abundant in road dust. Dust pollution was not important in Jūrmala where the roads have an asphalt cover.

The second PCA component was strongly correlated with $\mathrm{Pb}, \mathrm{Cu}$ and $\mathrm{Ni}$. No statistically significant correlations were found between Axis 2 and any of the measured distances. We could not explain this factor. The third PCA component was related with EC and concentration of K. Multiple re- gression showed that EC was related to distance to the sea. The source of salts to inland territories is sea-salt dispersed by winds (Franzén, 1990).

No significant correlations were found between most of the studied bioindicative characteristics. This may be explained by different time periods that were characterised by the bioindicators used in our study. Pine needle necroses and ozone induced mottling reflected 6 and 14 month periods while the content of metals in the surface layer of the pine bark evidently reflected accumulation of pollutants over a much longer period. On the other hand, lack of significant correlations suggests that spatial patterns of environmental stress factors differed. In any case, our hypothesis on the possible relationships between bioindicators had to be rejected. Our data showed that there may be at least three independent flows of air pollutants from different sources, which cause different types of damage to pine stands in the region: (1) air pollution or some other kind of environmental stress of unknown origin; (2) ground level ozone causing pine needle mottling; (3) dust from gravel roads accumulated in the surface layer of pine bark. Data on air chemistry in the region would be needed to determine the direct factors causing pine needle tip necroses. However, bioindication methods can be used independently of chemical analyses, considering that the effects of air pollutants on bioindicators depend not only on absulute concentrations but also on environmental factors such as air temperature, relative moisture, wind velocity etc. (Schubert, 1991). Our earlier studies showed that pine needle necroses can be promoted also by interaction of air pollution with natural environmental factors, such as prolonged drought (A. Karpa, personal communication).

Evidently, the source of metal pollution mostly arises from local sources, while the gaseous pollutants can be transported from more distant sources. Heavy metals are mainly emitted in the form of particulate material, and the distance they are transported is, compared to gaseous pollutants, relatively short. Traffic emissions on roads are the main cause of heavy metal accumulation in the surrounding environment and plant species (Ward et al., 1974; Grodzińska, 1977; Berina and Kalvin,a, 1989). In our case, the main sources of dust was gravel roads.

Mesoscale air circulation is very important from the point of view of how and where forest ecosystems are affected by point sources and regional air pollution. For example, ozone visual injury in Pinus helepensis Mill was observed to be well correlated with the penetration of sea breeze in Mediterranian coastal valleys (Sanz et al., 1999). Diffuse air pollution arises from vehicle emissions, which are mostly responsible for formation of ground ozone. Ozone is a regional pollutant formed through photochemical reactions in the atmosphere, reaching the highest concentrations hundreds of kilometres downwind of its precursor emission sources (Bealey, 2008).

Our study showed that environmental assessment of the $\mathrm{LT}(\mathrm{S}) \mathrm{ER}$ region by one bioindicator is not reasonable. Bet- 
ter results can be obtained by selecting several bioindicators, each characterising a particular type of environmental stress. However, our study showed that bioindication methods based on pine needles could be used for the environmental assessment of the region. Bioindicators used for mapping of the environmental pollution of a region should be sensitive and widely distributed. Scots pine Pinus sylvestris indicators fully comply with these requirements. Although pine forests in general are the most characteristic element of the landscape of the Engure region, in some parts of it was difficult to find suitable pine stands for bioindication. This may cause certain inaccuracies in mapping of environmental stress. To fill these gaps in bioindication, some other widely distributed species could be used, such as birch Betula pendula. Analysis of pine bark showed mostly local effects of road dust. Evidently, this type of pollution had no crucial effects on pine growth, as no correlations were found with pine needle damage. From this perspective, pine bark analysis is of less importance for the assessment of environmental pollution of the region.

\section{ACKNOWLEDGEMENTS}

The study was performed in the framework of the national cooperative project No. 10.0004 financed by the Council of Science of Latvia. We express our gratitude to K. Viligurs for analysis of metal concentrations in pine bark as well as A. Medene for preparation of some figures. We are grateful also to $V$. Balodis for valuable comments to the manuscript.

\section{REFERENCES}

Anonymous (2001). Submanual on Assessement of Ozone Injury on Intensive Monitoring Plots, Annex. UN Economic Commission For Europe Convention on Long-Range Transboundary Air Pollution. 21 pp.

Anonymous (2005). Ecosystems and Human Well-Being: Synthesis. Millennium Ecosystem Assessment (MEA) Washington, Island Press. 155 pp.

Anonymous (2005).Vides monitoringa programma [Environmental monitoring programme]. Available at: http://www.lvgma.gov.lv/vmp2005/, last accessed September 2011.

Anonymous (2011a). ILTER. Available at: http//www.ilternet.edu, last accessed September 2011.

Anonymous (2011b). National LTER Network of Latvia. Available at: http://www.lubi.edu.lv/index2.php?lang=2\&sid=115, last accessed September 2011.

Balodis, V., Kalviškis, K., Ramans, K., Liepa, I., Brūmelis, G., Magone, I., Nikodemus, O. (1993). Environmental assessment in Latvia: Overview of past research and future perspectives. J. Baltic Studies, 24(3), 223-232.

Bealey, W.J., Long, S., Spurgeon, D.J., Leith, I., Cape, J.N. (2008). Review and implementation study of biomonitoring for assessment of air quality outcomes. Bristol, Environment Agency, Science Report - SC030175/ SR2. $170 \mathrm{pp}$.

Choi, D.S., Kayama, M., Jin, H.O. Lee, C.H., Izuta, T., Koike, T. (2006). Growth and photosynthetic responses of two pine species (Pinus koraiensis and $P$. rigida) in a polluted industrial region in Korea. Environ. Pollut., 139(3), 421-432.

Bauer, M.L. de, Hernández-Tejeda, T. (2007). A review of ozone-induced effects on the forests of central Mexico. Environ. Pollut., 147(3), 446-453.

Franzén L.G. (1990). Transport, deposition and distribution of marine aerosols over Southern Sweden during dry westerly storms. Ambio, 19(4), 180-188.
Geras'kin, S., Evseeva, T., Oudalova, A. (2011). Plants as a tool for the environmental health assessment. In: Encyclopedia of Environmental Health (pp. 571-579). Nriagu J. (ed.). Elsevier.

Grodzińska, K. (1977). Acidity of tree bark as a bioindicator of forest pollution in southern Poland. Water Air Soil Pollut., 8, 3-7.

Harju, L., Saarela, K.-E., Rajander, J., Lill, J.-O., Lindroos, A., Heselius, S.-J. (2002). Environmental monitoring of trace elements in bark of Scots pine by thick-target PIXE. Nucl. Instr. Meth. Phys. Res., B, 189, 163-167.

Holt, E.A., Miller, S.W. (2011). Bioindicators: Using organisms to measure environmental impacts. Nature Education Knowledge, 2(2), 8, 1-5.

Jäger, H.J. (1980). Indikation von Luftverunreinigungen durch morphometrische Untersuchungen an Hohrer Pflanzen. In: Bioindikation, Teil 3 (pp. 43-52). Scubert R. \& Schuh J. (Hrsg.). Halle-Wittenberg: Wiss. Beitr. Martin-Luter-Univ., 26, 10.

Knabe, W. (1982). Monitoring of air pollutants by wild life plants and plant exposure: Suitable bioindicators for different immissions types. In: Monitoring of Air Pollutants with Plants (pp. 59-72). Steubing L., Jäger H.-J. (eds.). The Hague-Boston-London: Junk Publ.

Kord, B., Kord, B. (2011). Heavy metal levels in pine (Pinus eldarica Medw.) tree barks as indicators of atmospheric pollution. BioResources, 6(2), 927-935.

Linzon, S.N. (1960). The development of foliar symptoms and the possible cause and origin of white pine needle blight. Canad. J. Bot., 38, 153-161.

Lippo, H., Poikolainen, J., Kubin, E. (1995). The use of moss, lichen and pine bark in the nationwide monitoring of atmospheric heavy metal deposition in Finland. Water Air Soil Pollut., 85, 2241-2246.

Magone, I. (1992). Phytoindicative assessment of environmental quality in Latvia. III. Materials and methods. Environmental Monitoring in Latvia, No. 1, pp. 6-9.

Magone, I., Karps,A., Teivans, A. (1992). Phytoindicative assessment of environmental quality in Latvia. IV Phytoindication results. Environmental monitoring in Latvia, No. 1, p. 9-15.

Miller, P.R., Stolte, K.W., Duriscoe, D.M., Pronos, J. (Techn. Coordinators) (1995). Evaluating ozone air pollution effects on pines in the western United States. Albany, CA: Pacific Southwest Research Station, Forest Service, U.S. Department of Agriculture. 78 pp.

Nikodemus, O., Brūmelis, G., Līkais, S., Šarkovskis, P. (1993). Bioindication of pollutants in the Jūrmala area using Scot's pine (Pinus sylvestris) bark as a sorbent. Latvijas ZA Vēstis, Nr. 9, 54-57.

Piikki, K., Klingberg, J., Karlsson, P.E., Pihl Karlsson, G. \& Pleijel, H. (2008). Covariation in the diurnal variation in of ground-level ozone and temperature-nocturnal temperature inversions as a source of local variation in ozone exposure. Workshop Report. Ozone exposure and impacts on vegetation in the Nordic Countries and the Baltic States. Gothenburg, Sweden.

Pöykiö, R., Hietala, J., Nurmesniemi, H. (2010). Scots pine needles as bioindicators in determining the aerial distribution pattern of sulphur emissions around industrial plants. World Academy of Science, Engineering and Technology, 68, 315-318.

Rautio, P., Huttunen, S., Kukkola, E., Peura, R., Lamppu, J. (1998). Deposited particles, element concentrations and needle injuries on Scots pine along an industrial pollution transect in northern Europe. Environmental Pollution, 103, 81-89.

Richards, B.L.Sr., Taylor, O.C., Edmunds, G.F. Jr. (1968). Ozone needle mottle of pine in southern California. J. Air Pollut. Control Assoc., 18, 73-77.

Rozhkov, A.S., Mikhailova, T.A. (1993). The effects of fluorine-containing emissions on conifers. Berlin; Heidelberg: Springer Verlag. 143 pp.

Sanz, M.J., Calatayud, V., Calvo, E. (1999). Spatial pattern of ozone injury in aleppo pine and air pollution dynamics in the Mediterranean. In: Physics and Chemistry of the Earth, Part C: Solar Terrestrial \& Planetary Science, 24(5), 495-498.

Schubert, R. (Herausg.) (1991). Bioindikation in terrestrischen Ökosystemen. Jena: Veb Gustav Fischer Verlag. S. 338. 
Smith, W.H. (1990). Air Pollution and Forests. New York, Springer Verlag. $618 \mathrm{pp}$.

Tingey, D.T. (1989). Bioindicators in air pollution research - applications and constraints. In: Biologic Markers of Air-Pollution Stress and Damage in Forests (pp. 73-80). Committee on Biologic Markers of Air-Pollution Damage in Trees, National Research Council, National Academy Press, Washington D.C.

Ward, N.I., Brooks, R.R., Reeves, R.D. (1974). Effect of lead from motor vehicle exhausts on tree along a major through fare in Palmerstone North, New Zealand. Environ. Pollut., 6, 149-158.

Weinstein, L. H., Laurence, J. E. (1989). Indigenous and Cultivated Plants as Bioindicators. In: Biologic Markers of Air-Pollution Stress and Damage in Forests (pp. 195-204). Committee on Biologic Markers of Air-Pollution Damage in Trees, National Research Council, National Academy Press, Washington D. C.
Бериня Дз.Ж., Калвиня К. (1989). Распределение выпадений выбросов автотранспорта и загрязнение почв придорожной полосы [Distribution of transport emissions and pollution of soil along the roadsides]. В кн.: Воздействие выбросов автотранспорта на природную среду. Зинатне, Рига, с. 22-35 (in Russian).

Бериня Дз.Ж., Лапиня И.М., Мелецис В.П., Спуньгис В.В. (1989). Изучение воздействия эмиссии автотранспорта на почвенные микроартроподы с применением метода главных компонент [Investigation of the impact of highway transport emissions on soil microarthropods by the method of principal components]. В кн.: Воздействие выбросов автотранспорта на природную среду (с. 48-73). Рига: Зинатне (in Russian).

Карпс А.Э., Мелецис В.П., Спуньгис В.В., Шарковскис, П.А. (1989). Изучение воздействия выбросов автотранспорта на членистоногих травостоя [The impact of automobil transport exausts on grassland arthropods]. В кн.: Воздействие выбросов автотранспорта на природную среду (с. 74-101). Рига: Зинатне (in Russian).

Received 15 November 2011

\section{VIDES KVALITĀTES NOVĒRTĒJUMS ENGURES EZERA SATECES BASEINA TERITORIJĀ, IZMANTOJOT PARASTO PRIEDI KĀ BIOINDIKATORU}

Veikta vides kvalitātes novērtēšana Engures ezera sateces baseina teritorijā, kas Latvijas nacionālā ilgtermiṇa ekoloǵisko pētījumu tīkla (Latvia LTER) ietvaros pārstāv LT(S)ER reǵionu. Kā bioindikators izmantota parastā priede Pinus sylvestris L., kurai pētītas trīs bioindikatīvās pazīmes: nespecifiskā bioindikācija, ko raksturo skuju galu nekrotizācijas pakāpe, piezemes ozona bioindikācija, ko raksturo hlorotiski plankumi uz skujām, un mizas k̦īmiskās analīzes. Paraugi ievākti 40 vietās 2010. gada novembrī. Skuju galu nekrotizācijas pakāpe nepārsniedza 4. klases līmeni (maksimāli iespējama 6. klase). Ozona bojājumu pakāpi raksturojošā indeksa $I_{d a m}$ vērtības nepārsniedz 1.63 (maksimālā iespējamā vērtība 6). Daudzfaktoru lineārās regresijas analīze parādīja, ka pH(KCl), magnija un dzelzs saturs palielinās lauku lielceḷu tuvumā augošo priežu mizā. Savukārt elektrovadītspēja EC un ozona bojājumu līmenis uz pirmā gada skujām pieaug jūras tuvumā. Galveno komponentu analīzē pirmo asi raksturo lauku lielceḷu radīto putekḷu emisija, bet trešo asi sāḷ ienese no jūras. Netika konstatētas statistiski ticamas korelācijas starp pētītajiem bioindikatīvajiem rādītājiem, izṇemot pirmā un otrā gada ozona bojājumus. Secināts, ka katrs no tiem atspoguḷo specifisku piesārņojošo vielu plūsmu un tādēḷ nav aizvietojams. 